January 1956, Khrushchev declared that there was a choice between peaceful coexistence and the most destructive war in history.

Khrushchev was impressed by the 1955 test of the improved hydrogen bomb. East and West now shared an understanding that nuclear war was unacceptable, and they knew that the other side understood this too. At last Bohr's dream was realized that statesmen should appreciate that nuclear weapons are a mortal danger to the world and are not weapons of war.

I can give here only a bare outline of Holloway's book. There is a lot more in it. For instance, he gives a detailed, vivid account of the Soviet-US confrontation in atomic policy, how it led to the Marshall Plan, to the establishment of the Federal Republic of Germany and its currency and to the Berlin blockade and airlift - all of it based on extensive documentation. Holloway is also good on the Korean War and the related discussions in the Soviet Union, and tells of the fate of well-known Soviet scientists.

This is a must read for all who are interested in the influence of atomic weapons policy, the early Cold War or the interplay of technical competence and espionage, as well as those simply looking for a splendid detective story.

Hans A. Bethe is in the Newman Laboratory of Nuclear Studies, Cornell University, Itha ca, New York 14853-5001, USA. During the Second World War he was director of the theoretical physics division of the Los Alamos Atomic Scientific Laboratory.

\section{Best of British}

\section{F. H. Hinsley}

Test of Greatness: Britain's Struggle for the Atom Bomb. By Brian Cathcart. John Murray: 1994. Pp. 301. £19.99.

THE first British nuclear bomb was successfully exploded on 3 October 1952 in the Monte Bello islands off the northwest coast of Australia. This was the outcome of a programme - Brian Cathcart rightly calls it a struggle - that was propelled by a series of decisions stretching back to the second half of 1945. The decisions, which were so secret that the prime minister, Clement Attlee, did not consult or even inform his cabinet except for a few leading ministers (the Australian prime minister, Robert Menzies, followed suit), were prompted by the unilateral termination by the United States of the cooperation with Britain in the Manhattan Project which had produced the bombs dropped on Hiroshima and Nagasaki.

There were other considerations. A research programme seemed necessary if
Britain was to participate in the establishment of some system of international control of atomic energy, although the prospects of success were judged to be faint. Far stronger was the expectation that the Soviet Union would soon produce a bomb: the defector Igor Gouzenko disclosed in September 1945 that Alan Nunn May had passed information about the Manhattan Project to Moscow. Together with the realization that, as Attlee wrote within days of the explosions over Japan, the bomb had made nonsense of all previous thinking about the defence of Britain, these were the arguments that led to a rapid if not quite complete consensus behind the conclusion voiced in 1951 by William Penney, head of the team of scientists who designed the British bomb: "the discriminative test for a first-class power is whether it has made an atomic bomb". Ernest Bevin, the foreign secretary, is said to have made the point more colourfully in October 1946 to a cabinet committee dismayed at the estimated cost: "We've got to have this thing... whatever it costs.... We've got to have a bloody Union Jack flying on top of it."

A comprehensive account of these central political and strategic decisions, as also of the organizational, technological, financial and manpower problems to which they gave rise, and of how they were solved, was published in 1974 in the second volume of Margaret Gowing's official history, Independence and Deterrence: Britain and Atomic Energy, 1945-52. Cathcart provides a lucid summary of the official account and occasionally amplifies it where newly declassified documents allow. But decisions and developments at the higher levels, while they form the essential scaffolding for his book, are not his main concern. That is to relate how the project was brought to fruition at the workface, his prime sources the recollections of a wide cross-section of the scientists assembled by Penney to staff High Explosive Research, forerunner of the Atomic Weapons Research Establishment at Aldermaston, and of the representatives from the Royal Air Force, the Royal Navy and the Royal Engineers who were directly associated with them; and as these men have recently become free to discuss their experiences - although still within certain security constraints - the result is an original and absorbing contribution to our knowledge.

The team included none of the country's foremost scientists. Penney set his sights on making a near approximation to the plutonium implosion bomb used against Nagasaki, of which he had acquired general knowledge at Los Alamos and as an observer of its effects from the air and on the ground. For this he needed not a reconstitution of the British Los Alamos team, but technologists and technicians. More than half of them were in their 20s. They were, however, forced to work at and beyond the frontiers of their technological experience in chemistry and chemical engineering, nuclear physics, radiology, medicine and above all metallurgy. The refusal of the US authorities to provide information and material was offset by assistance from some of the British Los Alamos veterans. Notable among them was Klaus Fuchs; he had close knowledge of the Nagasaki weapon and, now head of theoretical physics at the Atomic Energy Research Establishment at Harwell, he placed this knowledge at Penney's disposal until in January 1950 he confessed that he had also assisted the Soviet Union, whose first nuclear test had recently been detected, and was jailed for treason.

Cathcart is not himself a scientist, and he has taken pains to make his account accessible, as literary critics say, to readers who labour under the same disadvantage. If the book has a fault it is that, between the fascinating story of the making of the bomb and the final drama of the test itself, it covers in equally great detail other matters, such as the transfer of the scientists and their equipment to Monte Bello and the preparations and rehearsals on the islands for the explosion, of which day-today and sometimes hour-to-hour accounts are bound to become tedious. But even this is a fault in the right direction: it completes the story and enhances its realism.

Eighty-five of the scientists and most of the equipment made the passage in cramped warships, and the voyage round the Cape took 59 days, 37 of them at sea. The Monte Bello islands held few species of wildlife and even fewer charms; and it causes no surprise to learn that hitches were frequent in the final preparations for so complex an undertaking in such hostile terrain. The truly serious hitch, not unlike that which had delayed and threatened to abort the Normandy landings in 1944, came at the end. If a lull in the unstable weather had not permitted a postponed explosion on 3 October, Cathcart doubts whether the expedition could have waited for the next suitable period.

$\mathrm{He}$ ends on an elegiac note. The success of the test marked only the entry of Britain into a race of indefinite duration - a race in which it was able to surmount the hurdle of the hydrogen weapon, a device first exploded by the United States in November 1952, but was thereafter outpaced by the development of ever more sophisticated delivery systems. He has no doubt, however, that Britain's decision to join in the race was justified, and he demonstrates that its success in doing so was a magnificent achievement.

Sir Harry Hinsley is at St John's College, Cambridge CB2 1TP, UK. During the Second World War he worked in the UK Government Code and Cypher School. 